\title{
Mnemotechniki, wersja (2.b). Dwa przykłady metodyczne na wykorzystanie dokumentu udostępnionego
}

\author{
Mnemotechnics, version (2.b). Two methodical \\ examples for the use of a shared document
}

\author{
$\mid \begin{aligned} & \text { Maciej Pabisek } \\ & \text { XX Liceum Ogólnokształcące im. L. Staffa w Krakowie }\end{aligned}$
}

\begin{abstract}
The article presents two scenarios that use a document shared in Google Drive to be used in a Polish language lesson. The first encourages high school students to create poetic pieces modeled on Jaroslaw Lipszyc's Mnemotechniki, that is cento. The second one suggests analyzing and interpreting Adam Naruszewicz's Balon in the context of a ship - the homeland's motif, which is done to a large extent by the students themselves.

Key words: shared document, Google Drive, cento, Jarosław Lipszyc, Adam Naruszewicz

Streszczenie: Artykuł prezentuje dwa scenariusze wykorzystujące w pracy na lekcji języka polskiego dokument udostępniony na Dysku Google. Pierwszy zachęca młodzież licealną do tworzenia utworów poetyckich wzorowanych na Mnemotechnikach Jarosława Lipszyca, tzw. centonach. Drugi - proponuje w dużej mierze przeprowadzoną samodzielnie przez uczniów analizę i interpretację ody Adama Naruszewicza Balon w kontekście motywu okrętu - ojczyzny.
\end{abstract}

Słowa kluczowe: dokument udostępniony, Dysk Google, centon, Jarosław Lipszyc, Adam Naruszewicz

Lekcje poświęcone poezji w szkole średniej natrafiają na szereg paradoksów. Z jednej strony wielu uczniów nie chce się przyznać, że wiersze czytać lubi albo - nie daj Boże - rozumie. Zatem analiza poezji zwłaszcza w kontekście ćwiczeń maturalnych traktowana jest jako zło konieczne. Z drugiej to przecież czas pierwszych poważniejszych prób literackich czy poetyckich, mniej lub bardziej jawnych, a na pewno budzących dużo emocji związanych z recepcją własnej twórczości w gronie znajomych. Sprzeczność ta powoduje, że polonista nigdy nie może być do końca pewien, czy aktualnie czytana twórczość poetycka potraktowana zostanie obojętnym wzruszeniem ramion, czy wzbudzi entuzjazm.

Tekst zawiera dwa projekty pracy z poezją polską, które - po pierwsze - pozwalają zapoznać młodzież z nieoczywistą formą współczesnych dzieł literackich, po drugie - wzmacniają w atrakcyjny sposób kompetencje 
literackie czy kreatywne związane z interpretacją poezji z wcześniejszych epok. Przywołane przykłady należy traktować jako punkt wyjścia w realizowaniu własnych pomysłów edukacyjnych. Zaproponowana metoda wykorzystuje nowoczesne środki multimedialne i chociaż w skrajnych przypadkach może się bez nich obejść, to jednak wtedy traci większość atutów metodycznych poza celami poznawczymi.

\section{Lekcja pierwsza - Mnemotechniki}

Kiedy Jarosław Lipszyc stworzył swoje Mnemotechniki, jego dokonanie uznano za przejaw najbardziej awangardowych tendencji w neolingwizmie, czyli nurcie poetyckim odwołującym się do tradycji poetyckich wypracowanych przez polskich eksperymentatorów językowych tworzących w połowie XX wieku. Chociaż twórcy związani z tym kierunkiem wyznaczali sobie różne cele, łączyło ich przekonanie o potrzebie strukturalistycznego oglądu budowy utworu poetyckiego. $\mathrm{W}$ ich dokonaniach zainteresowanie wzbudzał przede wszystkim materiał językowy jako ośrodek komunikatu. W nieoczywisty sposób, niejako przy okazji, doprowadziło to do uzyskania w tekście nowych znaczeń.

Autor Mnemotechnik wyszedł z założenia, że w nowoczesnym świecie rolę naturalnego komunikatu przejmuje coraz bardziej język wtórny, opracowany w Internecie i używany na jego potrzeby. Język ten tylko pozornie pozwala wskazać na swych autorów. W istocie w „Wikipedii, mimo że lista autorów kolejnych modyfikacji haseł jest dostępna, samo pojęcie autorstwa pozostaje rozmyte" ${ }^{1}$. Zamieszczone hasła w każdej chwili mogą ulegać (i ulegają) edycji. W efekcie zmienia się nie tylko ich treść, ale problematyczne staje się wskazanie twórcy. Pod tym względem komunikacja internetowa przypomina więc mowę naturalną.

Lipszyc postanowił $\mathrm{w}$ tym języku napisać?, wyedytować?, skompilować? dzieło składające się z cyklu utworów. W nim: „każdy z wierszy składa się ze zdań, słów, liter, które wyjęte są z haseł polskiej edycji Wikipedii, do których autor zamieszcza nawet adresy pod każdym z utworów" Dokonanie to miałoby być kolejnym krokiem na drodze do udowodnienia... no właśnie: autonomizacji poezji, jej odpodmiotowienia, a może - jej zdolności autokreacyjnych?

Jedna z teorii interpretacyjnych może wieść do przekonania, że według autora Mnemotechnik twórczość... pisząc się sama, nie tyle potrzebuje autora, co czytelnika. Odbiorca nadaje sens określonemu dziełu w konkretnym odczytaniu, dając po prostu jednostkowo wybranym słowom czy frazom pierwszeństwo semantyczne $\mathrm{w}$ momencie konkretnego odczytania. Nic zatem nie stoi na przeszkodzie, aby w kolejnej lekturze przyznał pierwszeństwo innym słowom, które odmienią rozumienie liryku. A zatem,

\footnotetext{
${ }^{1}$ A. Pająk, http://www.techsty.art.pl/magazyn/magazyn5/recenzje/mnemotechniki.html [dostęp 2903 2018]

2 Tamże.
} 
konsekwentnie rozumując, pisarz nie jest nikim innym jak czytelnikiem, który wybiera z ogromnego zbioru języka mniej lub bardziej gotowe zwroty (modni krytycy powiedzieliby - klisze) i daje im interpretacyjne pierwszeństwo. Od „zwykłego” czytelnika różni się zaś tylko tym, że swe wybory utrwala, zapisując czy publikując.

Oczywiście, jeśli pomysł Jarosława Lipszyca rozpatrywać w kontekście techniki wykonania, nie jest on niczym nowym dla lingwizmu. Już w starożytności pod nazwą centonów znano praktyki kompilowania i łączenia na nowo wierszy mniej lub bardziej znanych twórców. Tendencje te powróciły również w poezji barokowej czy awangardowej.

Najbardziej spektakularny w swych dokonaniach był w latach 60 . ubiegłego wieku Raymond Queneau, który w zbiorze poezji Sto tysięcy miliardów wierszy wydał cykl 10 sonetów, wydrukowanych na kartkach pociętych na paski. Toteż każdą linijkę wiersza czytelnik może dowolnie podmieniać, co umożliwia mu samodzielne wygenerowanie na drodze kombinatoryki i permutacji niemal nieskończonej liczby wierszy.

Z kolei prekursorem tego typu twórczości w sieci jest Lance Newman. Autor od 2006 roku proponuje czytelnikom swojego bloga 3by3by3.blogspot. com³ $^{3}$ czytanie wierszy, których kanwą stał się język artykułów z Internetu. W tym przypadku nazwa bloga odwołuje się do zasady tworzenia utworów, którą narzucił sobie poeta:

Weź 3 teksty z Google News. Używajac tylko słów, które pojawia się w pierwszych 3 paragrafach każdej z informacji. Ułóż wiersz z 3 strofami, każda po 3 wersy nie większe niż 60 znaków w linii. Tytuł powinien mieć 3 słowa i musi wykorzystywać jeden wyraz $z$ każdego newsa ${ }^{4}$.

Wydaje się jednak, że propozycja polskiego poety jest o wiele ciekawsza. Między innymi dlatego, iż w Mnemotechnikach zostaje zmieniony styl wypowiedzi. Zwraca na to uwagę Leszek Onak:

O dziwo teksty te dają się przeczytać. Pomimo że powstały jako zlepek haseł encyklopedycznych, czyli nudnych, naukowych notek, które nastawione są na przekazywanie informacji, to wiersze te mają sens i ciekawie się je czyta ${ }^{5}$.

Obecnie, po upływie 10 lat, gdy urok nowości Mnemotechnik skutecznie zastąpiony został przez kolejne eksperymenty nowatorów poetyckich, propozycja prezesa Fundacji Nowoczesna Polska wciąż pozostaje atrakcyjna dla kolejnych pokoleń czytelników i... naśladowców. Ostatnie zdanie nie pozostaje pustą deklaracją, o czym przekonują prace uczniów klasy 2b, dla których spotkanie z twórczością Jarosława Lipszyca stało się nie tyle nawet formą intelektualnego wyzwania, co artystycznej realizacjí.

\footnotetext{
${ }^{3}$ http://3by3by3.blogspot.com [dostęp 3003 2018]

${ }^{4}$ Cyt za: A. Pająk, http://www.techsty.art.pl/magazyn/magazyn5/recenzje/mnemotechniki.html [dostęp 2903 2018]

${ }^{5}$ L. Onak, http://niedoczytania.pl/jaroslaw-lipszyc-publikuje-mnemotechnike/[dostęp 0804 2018]

${ }^{6}$ Klasa 2b w momencie przeprowadzenia lekcji (marzec 2018) uczęszczała do XX Liceum Ogólnokształcącego w Krakowie.
} 


\section{Mnemotechniki na lekcji}

Lekcja $\mathrm{w}$ założeniu posiada kilka celów $\mathrm{z}$ różnych poziomów. Merytoryczne - związane są z zapoznaniem z twórczością Jarosława Lipszyca, uaktualniają wymowę Lalki Bolesława Prusa, wprowadzają w specyfikę kodów językowych czy refleksję nad różnicą pomiędzy kulturą wysoką i popularną. Socjologiczne - uczą współpracy w zespole oraz unaoczniają możliwości, które oferują nowoczesne narzędzia komunikacyjne w zakresie kooperacji. Wreszcie cele artystyczne pozwalają na wyrażenie swej wrażliwości artystycznej.

Lekcja zyskuje na atrakcyjności dla ucznia, jeśli końcowe działania młodzieży zostaną przeprowadzone w przestrzeni wirtualnej, niejako na żywo. Wymaga to założenia przez uczniów konta na gmailu, jednej z internetowych aplikacji. Pozwala ona nie tylko otrzymywać pocztę, ale również edytować wspólnie dokumenty, co jest dodatkowym atutem zaproponowanej metody.

W przypadku gdyby trudności techniczne uniemożliwiały przeprowadzenie zajęć „online”, można lekcję przeprowadzić w tradycyjny sposób, koncentrując się na jej celach artystycznych. Tekst dostępny jest bowiem także w wersji papierowej, w podręczniku do języka polskiego Nowe lustra świata, cz. $3^{7}$.

\section{Przebieg lekcji pierwszej}

Realizację tematu rozpoczyna przeczytanie tekstu Jarosława Lipszyca Lalka Barbie ${ }^{8}$, przy czym nauczyciel wstrzymuje się z odczytaniem odnośników do stron Wikipedii. Przeprowadzona następnie analiza skupia się na relacjach: Wokulski - Ken, Łęcka - Barbie. W tym celu polonista może podzielić klasę na dwie grupy. W obrębie każdej z nich przykładowe pytania mogą brzmieć: co łączy, a co dzieli Barbie i Kena; jakie zdarzenia/przygody są ich udziałem; jakie jest zakończenie omawianych utworów, jak uczniowie je oceniają i czy coś by w nich zmienili.

$\mathrm{Na}$ przeprowadzonych zajęciach młodzież dostrzegła, że przygody bohaterów opisanych w Lalce Barbie nie są oryginalne, lecz inspirowane akcją powieści pozytywistycznej. Toteż na każde z postawionych zagadnień odpowiadać można dwojako, biorąc pod uwagę pozytywistyczny pierwowzór lub go pomijając. W pierwszym przypadku Barbie i Ken to nikt inny jak Izabela Łęcka i Stanisław Wokulski. Ich perypetie w ocenie młodzieży wydają się też zmierzać do optymistycznego zakończenia.

$\mathrm{Na}$ tym etapie polonista może zwrócić uwagę na wagę kontekstu odczytania każdego utworu literackiego, który w znaczący sposób wpływa na przesłanie dzieła. W omawianym przypadku będą to na przykład: masowe zainteresowanie produktami firmy Mattel, wymagająca więcej dojrzałości recepcja powieści realistycznej.

${ }^{7}$ Lipszyc J., 2014, Lalka Barbie, w: Bobiński W., Janus-Sitarz A., Pabisek M., 2014, Nowe lustra świata, Warszawa, cz.3, s. 322-323.

8 https://pl.wikisource.org/wiki/Lalka_Barbie [dostęp 1303 2018] 
Co ciekawe, uczniowie sami z siebie dają się uwieść narracji utworu i w pierwszej chwili nie dostrzegają wieloznaczności zakończenia dzieła Jarosława Lipszyca. Dopiero zachęceni przez nauczyciela zauważają także możliwość nieoptymistycznego rozwiązania relacji Kena i Barbie. Nauczyciel może pogłębić analizę wiersza, porównać jego wymowę z zakończeniem losów głównych bohaterów Lalki, zapytać o emocje, które budzą u uczniów poszczególne realizacje.

Z kolei prowadzący zachęca uczniów do wskazania pozytywnych i negatywnych konsekwencji dokonanego zestawienia Lalki i lalek. W trakcie lekcji młodzież dyskutowała o skutkach „uwspółcześnienia” historii bohaterów powieści; o cenie popularyzacji sztuki wysokiej, ale też deprecjacji (nobilitacji); o relacji pomiędzy uniwersalnością a indywidualnością ludzkiej egzystencji.

Następna część zajęć poświęcona jest analizie funkcji wprowadzonych do Mnemotechnik przypisów - linków odsyłających do wikipedycznych haseł inspirujących ich autora.

Ten element lekcji wiąże się z poszukiwaniem w Internecie źródeł i inspiracji dla tekstu. Polonista zadaje pytanie o sposób wykorzystania Wikipedii, pozwala na swobodne wypowiedzi dotyczące różnorodnych doświadczeń i refleksji użytkowników wirtualnej encyklopedii. Następnie umiejscawia Lalkę Barbie w kontekście całości zbioru Mnemotechnik. Może krótko porozmawiać o etymologii samego słowa, o zasadzie budowy poszczególnych tytułów składających się na poetycki zbiór, wreszcie - wprowadzić uczniów w istotę i historię tworzenia centonów lub zapytać o skojarzenia czy ocenę tego typu działalności literackich. Ostatnim elementem tego fragmentu zajęć jest ukazanie oryginalności projektu Jarosława Lipszyca na tle poprzedników. $\mathrm{W}$ tym celu nauczyciel zaprasza do rozmowy na temat miary z jednej strony anonimowości Mnemotechnik, a z drugiej oryginalności projektu. Warto założyć, że uczniowie generalnie nie posiadają wiedzy o modernistycznych realizacjach literackich. Innym istotnym tematem dyskusji klasowej będzie wątek konsekwencji wykorzystania języka internetowego (ważność, komunikatywność, estetyka) w procesie pisania artystycznego.

Na koniec zajęć klasa wraca do podziału na kilkuosobowe grupy. Młodzież w ramach zespołów pisze wiersz metodą zaproponowaną przez Lipszyca. Jeśli skończy przed dzwonkiem, może zapoznać klasę z efektem swoich działań poetyckich.

Wyobraźnię uczniów zapewne pobudzi udostępnienie im dokumentu,

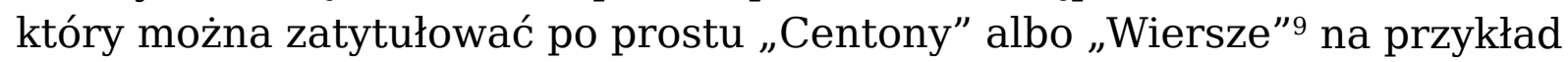
za pomocą Google Documents. W nim poszczególne grupy mogą edytować swe prace jednocześnie w trakcie trwania lekcji. Innym narzędziem służącym temu samemu celowi może być Blogger, o ile nauczyciel założył na nim wcześniej bloga. W jednym i drugim przypadku polonista powinien

\footnotetext{
${ }^{9}$ Dokument poza tytułem jest pusty w chwili rozpoczęcia pracy. Warto w komentarzu do niego napisać prośbę do użytkowników o nieusuwanie żadnych treści.
} 
wyświetlić edytowany dokument za pomocą rzutnika multimedialnego, tak aby młodzież obserwowała postęp pracy w czasie rzeczywistym. Istnieje też możliwość internetowego uzupełniania opracowywanego dokumentu po zakończeniu lekcji.

Gdyby uczniowie nie mieli pomysłu na wikipedyczne hasła nadające się do wykorzystania przy pisaniu wierszy, prowadzący może im zaproponować te, związane z epoką i/lub twórczością Prusa (np. pozytywizm, praca u podstaw, powieść, patriotyzm, felieton, realizm itd.)

Udostępnienie napisanych wierszy za pomocą aplikacji Dysk Google Documents i wyświetlenie ich w czasie rzeczywistym pozwala młodzieży na jeszcze jedną aktywność - przeczytanie oraz poddanie refleksji czy opiniom członków pozostałych grup.

\section{Lekcja druga - Balon}

Trudno szukać w polskiej liryce przedromantycznej wiersza o większym ładunku optymizmu niż ten zawarty w odzie Balon. Optymizm dotyczy zarówno ludzkiej natury, którą podmiot liryczny ocenia ze względu na przymioty rozumu, dającemu ludzkości przewagę w konfrontacji z prawami natury, jak również przyszłości Polski. Tym dziwniejszy wydaje się fakt, że tak rzadko oda ta trafia do wyboru wierszy w szkolnych podręcznikach. Być może w jakimś stopniu wytłumaczeniem jest niezgodność historyków literackich co do autorstwa ody. Część utrzymuje, że wiersz napisał Adam Naruszewicz, część - że Stanisław Trembecki. Ten ostatni będąc w potrzebie pieniężnej, sprzedał - jak miewał w zwyczaju - napisany przez siebie utwór koledze po piórze.

Zapewne nie bez znaczenia pozostaje fakt, że problematyka Balonu źle się wpisuje w narrację mówiącą o udręczonym narodzie, którego tylko najświatlejsi przedstawiciele dostrzegają zagrożenie upadku państwowości i apelują w kolejnych dziełach, by odmieniać system wartości, poprawiać swe zachowanie, eliminować wady.

Tymczasem wiersz z jednej strony wieszczący Sarmatom optymistyczną przyszłość, z drugiej - deklarujący wiarę w ludzki rozum, w kontekście nie tak odległego już upadku państwowości, stawia pod wielkim znakiem zapytania także i siłę racjonalizmu ludzkiego...

Zazwyczaj omawia się Balon w opozycji do wybranych satyr Ignacego Krasickiego, wskazując na szerokie horyzonty poznawcze przedstawicieli polskiego oświecenia, którzy potrafili zdobyć się na przekrojowy opis natury ludzkiej. Znajduje się w niej przecież miejsce i na wielkość przedsięwzięć, i na moralną małość. Oda i satyra na zasadzie przeciwieństwa skupiają w klasycystycznej soczewce panoramę osiemnastowiecznej Rzeczpospolitej, w której małe - chociaż opornie - to jednak ustępuje miejsca wielkiemu. 
W tym kontekście nietrudno zrozumieć zachwyt autora ody. Obserwacja startującego balonu ${ }^{10}$ wywarła na nim niezatarte wrażenie i skłoniła do optymistycznych w swym przesłaniu refleksji, mimo rzucających się w oczy objawów rozkładu państwa.

Z oczywistych względów mierzenie się człowieka z żywiołem powietrza było w tamtych czasach najbardziej spektakularnym wyrazem ludzkich aspiracji w podporządkowywaniu sobie natury. W wielu państwach Europy - lubiącej siebie nazywać oświeconą - trwały równoległe prace nad możliwością pokonania sił grawitacji. Co ciekawe, na początku najważniejsza rola należała do... chemików, którzy zmierzyć się musieli z problemem wyprodukowania na skalę produkcyjną odpowiedniego nośnika balonu - gazu o specyficznych cechach.

Chociaż ostatecznie pierwszeństwo przypadło francuskim braciom (Joseph Michel Montgolfier i Jacques Étienne Montgolfier ${ }^{11}$ ) jako autorom projektu jedwabnego balonu wypełnionego rozgrzanym powietrzem, także i Polacy brali udział w tej niezwykłej przygodzie naukowej. Jan Śniadecki na terenie obserwatorium astronomicznego w Krakowie ${ }^{12}$ wypuszczał modele balonów (na uwięzi) wykonane z papieru i napełniane wodorem. Zapewne część informacji o naturze i stanie prac związanych z lotami balonowymi nie była obca też autorowi ody.

W zaproponowanym tutaj ujęciu nie rezygnuje się z wyartykułowania optymistycznych cech utworu. Jednak analizuje się je w bardziej uniwersalnym kontekście toposu ojczyzny-okrętu. Takie podejście pozwała nie tylko odejść od historycznoliterackiego ujęcia, ale uczynić z niego uniwersalne przesłanie wiary w możliwości człowieka. Znamienne, że tuż przed upadkiem I Rzeczpospolitej powstał wiersz, który wieszczył jej synom wspaniałą przyszłość. Autorzy wcześniej podejmujący ten motyw i bardziej sceptycznie oceniający w wierszach narodowy charakter Polaków - rozbioru Polski nie zaznali.

\section{Przebieg lekcji drugiej}

Zajęcia rozpoczyna podzielenie klasy na grupy, w których co najmniej jeden uczeń ma dostęp do konta w usłudze gmail i urządzenie gwarantujące połączenie się z pocztą mailową w trakcie lekcji. Następnie polonista głośno czyta wiersz Balon Adama Naruszewicza, rozdawszy uprzednio tekst. Nauczyciel może zadać pytanie o temat

\footnotetext{
10 Według Wikipedii: Jean Pierre François Blanchard (ur. 4 lipca $1753 \mathrm{w}$ Les Andelys, zm. 7 marca 1809 w Paryżu) w niedzielę 10 maja 1789 roku, krótko po godz. 13, wystartował z ogrodu Foksal w Warszawie, w obecności króla Stanisława Augusta Poniatowskiego. W powietrzu znajdował się 49 minut, osiągnął wysokość 2, a może nawet 3,5 km i wylądował w Białołęce. Był to jego 34 . udany lot balonem w karierze. Informacja za: https://pl.wikipedia.org/wiki/Jean-Pierre Blanchard [dostęp 0306 2018]

11 Pierwszymi pilotami balonu byli ochotnicy: Jean François Pilâtre de Rozier i François Laurent d'Arlandes.

12 Wtedy obserwatorium mieściło się w budynku położonym przy ul. Mikołaja Kopernika w Krakowie, dzisiaj to teren Ogrodu Botanicznego.
} 
wiersza czy odczucia uczniów po jego wysłuchaniu. Z uwagą przysłuchuje się wstępnym rozpoznaniom.

Z kolei przystępuje do podania pierwszej instrukcji. Początkowe zadanie polega na wyjaśnieniu znaczeń wskazanych słów mogących sprawić trudność w ich zrozumieniu. Uczniowie mogą uzupełnić listę o kolejne nieznane sobie słowa, jeśli widzą taką potrzebę. Prowadzący lekcję aprobuje (lub nie) zgłaszane propozycje i udostępnia poszczególnym grupom fragmenty wiersza z zaznaczonym słowami i instrukcją.

Instrukcja 1 i materiał do jej wypełnienia: Wyjaśnij znaczenie podanych słów w najbardziej lakoniczny (zwięzły) sposób, w jaki potrafisz. W razie trudności skorzystaj z dostępnych źródeł wiedzy. Odpowiedzi zapisz w udostępnionym dokumencie.

\begin{tabular}{|l|l|}
\hline Grupa A & Grupa B \\
Bystry - & Rudel - \\
Pierzchliwe - & Potrząska - \\
Podniebie - & Zlepek - \\
Przodkować - & \\
\hline Grupa C & Grupa D \\
Gmin - & Poruczyć - . \\
Kryślić - & Skakać głazy nauczyć - \\
Roić - & Zbywać- \\
Latawiec - & Woda opuszcza doły - \\
& Styr - \\
\hline
\end{tabular}

Po wykonaniu zadania w udostępnionym dokumencie uczniowie otrzymują kolejną instrukcję. Celem zadania jest poszukanie informacji na temat podkreślonych słów. Zdobyta wiedza przybliży im realia historyczne, które wzbogacą kontekstowe rozumienie wiersza i pomogą w jego pełniejszej interpretacji.

Instrukcja 2: Korzystając z dostępnych źródeł, napisz krótką informację (od 20 do 40 słów) o podkreślonych wyrazach. Pamiętaj, by były one funkcjonalne względem analizowanego tekstu. Odpowiedzi zapisz w udostępnionym dokumencie.

\begin{tabular}{|l|l|}
\hline Grupa A & Grupa B \\
Ikar & Sarmata \\
\hline Grupa C & Grupa D \\
Natura & Blanchard \\
\hline
\end{tabular}

Jego zakończeniem (tak jak poprzednio) będzie umieszczenie notatek w odpowiednim miejscu udostępnionego dokumentu i ich późniejsza ustna prezentacja. 
Trzeci etap dotyczy budowania interpretacji całego wiersza. Każda grupa odpowiedzialna będzie za jego określony fragment.

Instrukcja 3: Odpowiedzi na zadane pytania zapisz w udostępnionym dokumencie.

\begin{tabular}{|c|c|}
\hline Grupa A & Grupa B \\
\hline $\begin{array}{l}\text { Przedstaw powody, dla których autor, } \\
\text { pisząc o współczesnych (sobie) zdarze- } \\
\text { niach, odwołuje się do mitologicznych } \\
\text { bohaterów. }\end{array}$ & $\begin{array}{l}\text { Wymień na podstawie tekstu zasługi, któ- } \\
\text { re bohater liryczny przypisuje ludzkiemu } \\
\text { rozumowi. }\end{array}$ \\
\hline Grupa C & Grupa D \\
\hline $\begin{array}{l}\text { W kontekście wiedzy o wartościach epoki } \\
\text { oświecenia określ stosunek podmiotu } \\
\text { lirycznego do rozumu (weź pod uwagę } \\
\text { sposób wypowiadania się o nim; przywo- } \\
\text { łane obrazy; zadania, które przed nim } \\
\text { stawia). }\end{array}$ & $\begin{array}{l}\text { Wyjaśnij, co łączy Blancharda i Sarma- } \\
\text { tę. (Dlaczego autor zdecydował się ich } \\
\text { zestawić w tekście wiersza?). }\end{array}$ \\
\hline
\end{tabular}

Interpretacja wiersza na tym etapie lekcji wydaje się kluczowa dla zrozumienia przesłania utworu, toteż nauczyciel może uważniej spojrzeć na pracę uczniów grup B, C i D. Zapewne najczęściej będą oni zwracać uwagę na zalety rozumu, który pozwala człowiekowi stopniowo (za)panować nad światem. Warto, aby polonista zapytał (jeśli młodzież tego nie wyartykułuje), w jakim stopniu przedmiotem analizowanej dumy jest fakt bycia Polakiem.

W tym momencie nauczyciel osadza przesłanie wiersza na tle idei epoki oświecenia. W tym celu przeprowadza pogadankę heurystyczną. Pytania, które może zadać na tym etapie lekcji, zmierzają do ukazania tematyki wiersza na tle zainteresowań literackich innych twórców oświeceniowych (Ignacy Krasicki czy Wolter) albo nawet - syntetycznych informacji o epoce.

W ostatniej części zajęć prowadzący przywołuje (o ile nie został dostrzeżony wcześniej przez uczniów) motyw ojczyzny - okrętu. Najlepiej służy temu celowi prezentacja multimedialna zawierająca stosowny fragment Kazań sejmowych Piotra Skargi:

Gdy okręt tonie, a wiatry go przewracają, głupi tłomoczki i skrzynki swoje opatruje i na nich leży, a do obrony okrętu nie idzie, i mniema, że się sam miłuje, a on się sam gubi. Bo gdy okręt obrony nie ma, i on ze wszytkim, co zebrał, utonąć musi. A gdy swymi skrzynkami i majętnością, którą ma w okręcie, pogardzi, a z innymi się do obrony okrętu uda, swego wszytkiego zapomniawszy: dopiero swe wszytko pozyskał i sam zdrowie swoje zachował. Ten namilszy okręt ojczyzny naszej wszytkich nas niesie, wszytko w nim mamy, co mamy. Gdy się z okrętem źle dzieje, gdy dziur jego nie zatykamy, gdy wody z niego nie wylewamy, gdy się o zatrzymanie jego nie staramy, gdy dla bezpieczności jego wszytkim, co w domu jest, nie pogardzamy: zatonie, i z nim my sami poginiemy. W tym okręcie macie syny, dzieci, żony, 
imienia, skarby, wszytko, w czym się kochacie. W tym tak wiele dusz jest, ile ich to królestwo i państwa przyłączone mają ${ }^{13}$.

Intencją porównania tych tekstów jest wskazanie na odświeżające ujęcie motywu dokonane przez oświeceniowego poetę, który żeglugę okrętem „zamienił” na żeglugę powietrzną. Zmiana ta służyła optymistycznej reinterpretacji (względem tradycyjnego ujęcia). Żeglarz nie wygląda burzy, nie obawia się o zachowanie współrodaków, którzy w sytuacji zagrożenia mogliby się zająć ratowaniem własnego majątku (zamiast ojczyzny) - natomiast patrzy śmiało w przyszłość podbudowany wiarą w potęgę ludzkiego rozumu, jaka podporządkowuje człowiekowi naturę i pozwala dostrzec, że: „Mocarskich siedlisk ogromy” zamieniają się „W gruzów nikczemnych potrząskę lichą", jeśli tylko popatrzeć na nie z odpowiedniej perspektywy.

Sformułowanie tego lub podobnego wniosku kończy zajęcia.

\section{Podsumowanie}

W ciągu dziesięciu lat znaczna część wikipedycznych haseł, które poeta wykorzystał do napisania Mnemotechnik, poddana została edycji. Wyraźne zmiany dotknęły artykuł poświęcony Lalce Bolesława Prusa. W poprzedniej wersji jego pokaźną część stanowiło streszczenie akcji, czego wyraźny ślad dostrzec można także w zapisie wiersza Lalka Barbie. W obecnej wersji tematyka i sposób realizacji dokonań uczniowskich wskazują na ich zainteresowanie materią języka czy w ogóle istotą komunikacji (a nie na przykład perypetiami bohaterów pozytywistycznej poezji). Można by nawet zaryzykować twierdzenie, że Jarosław Lipszyc powinien być dumny z ich osiągnięć. Z drugiej strony, uczniowie wzięli na warsztat interesujące ich zagadnienia, które poddali osądowi własnej wrażliwości.

Z niejakim zdumieniem można pochylić się nad ironią dziejów, które wniwecz obracają najbardziej śmiałe marzenia ludzkości. Potwierdzeniem jest chociażby przykład wieszczby zawartej w Balonie. Przyszłość przyniosła Sarmatom zamiast oczekiwanych lat chwały kolejne rozbiory, wojnę i przeszło 120 lat zaborów. Z drugiej jednak strony - czy nie jest zadaniem poetów w nawet najtrudniejszych czasach dawać ludziom nadzieję i wspierać ich marzenia?

Rzecz jasna, do powyższych wniosków można by dotrzeć za pomocą lekcji przeprowadzonych w bardziej tradycyjny sposób. Pominiemy jednak wtedy nie tylko zawsze atrakcyjną możliwość śledzenia postępu swojej pracy na żywo, ale również - bardzo istotny obecnie aspekt pracy grupowej. Synergia, która zostaje wytworzona, doprowadza do wyników nieosiągalnych w pracy uczniowskiej dokonanej w sposób klasyczny. Zajęcia wykorzystujące aplikację Dysk Google kładą nacisk na podmiotowość młodzieży. Od osobistego udziału poszczególnych uczestników lekcji zależy ostateczny

13 P. Skarga, Kazanie wtóre ze zbioru „Kazań sejmowych”. Tekst za: https://literat.ug.edu.pl/ skarga/0002.htm [dostęp 0106 2018]. 
wynik notki lekcyjnej. Wkład uczniów w zajęcia jest realny, ich wysiłek widoczny. Jednocześnie nauczyciel w naturalny sposób pozbawia się części swych dotychczasowych uprawnień. Czy jesteśmy na to gotowi?

\section{Centony internetowe, propozycje klasy $2 b^{14}$}

Wiersze napisane przez uczniów klasy 2b i udostępnione za pomocą aplikacji Dysk Google Documents - wersja oryginalna.

\section{Literatura filmu}

Magdalena Kołodziejczyk

Sylwia Kubala

Mariola Siepak

Sensowne twory słowne

Składające się ze scen

Dzieła artystyczne

Do kilkudziesięciu ujęć

Dzieli się zwykle na trzy

Zachowane w formie pisanej

Lub przekazie ustnym

Również w telewizji

Podstawowy i najbardziej popularny

Dzieli się zwykle według tradycji

Uzupełnianej później

Aktorski film fikcji

Źródła:

https://pl.wikipedia.org/wiki/Film

https://pl.wikipedia.org/wiki/Literatura

\section{Zbrodnia klasyczna}

Urszula Kubacka

Czyn człowieka

doskonały, pierwszorzędny

Spotyka się z potępieniem w muzyce i sztuce

Termin zawsze odnoszono do zbrodni kultury starożytnych Greków i Rzymian

Jak i zbrodni przeciwko majestatowi antyku

Źródła:

https://pl.m.wikipedia.org/wiki/Zbrodnia

https://pl.m.wikipedia.org/wiki/Klasycyzm

${ }^{14}$ Edycja oryginalna, zaproponowana przez poszczególne grupy piszących.

$$
\text { Polonistyka. Innowacje }
$$




\section{Wikipedyczny wiersz}

\section{Paulina Pawlik}

$\mathrm{Tu}$,

gdzie otwarta systemowa treść przedstawiana prozą,

powtarzam nie-systemowe odcinki pisane jej przeciwieństwem.

Umożliwiona edycja dla każdego,

kto użytkuje.

$\mathrm{Tu}$,

gdzie wielojęzyczne dzieło internetu,

wykorzystujące oprogramowanie MediaWiki...

rozbiegają się po sieci środki stylistyczne

cyfrowych użytkowników googla.

Sposób organizacji tekstu w umyśle czytelnika

aktualizuje się w czasie rzeczywistym.

Źródła:

https://pl.wikipedia.org/wiki/Wikipedia

https://pl.wikipedia.org/wiki/Wiersz

\section{Bibliografia}

Lipszyc Jarosław, 2014, Lalka Barbie, w: Bobiński W., Janus-Sitarz A.,

Pabisek M., Nowe lustra świata, cz.3, Warszawa, s. 322-323.

Naruszewicz Adam, https://pl.wikisource.org/wiki/Oda_balon [dostęp 1307 2018]

Newman Lance, http://3by3by3.blogspot.com [dostęp 3003 2018]

Onak Leszek, http://niedoczytania.pl/jaroslaw-lipszyc-publikujemnemotechnike/[dostęp 0804 2018]

Pająk Andrzej, http://www.techsty.art.pl/magazyn/magazyn5/recenzjel mnemotechniki.html [dostęp 2903 2018]

Skarga Piotr, Kazanie wtóre ze zbioru „Kazań sejmowych”, za: https://iterat.ug.edu.pl/skarga/0002.htm [dostęp 0106 2018]

\section{O Autorze:}

Maciej Pabisek, dr, absolwent Uniwersytetu Jagiellońskiego, doktor literaturoznawstwa, od kilkunastu lat nauczyciel dyplomowany w XX Liceum Ogólnokształcącym im. L. Staffa w Krakowie; autor kilkunastu artykułów popularyzujących nowoczesne metody nauczania, z których niektóre stały się lekturami dla studentów polonistyki; współautor cyklu podręczników szkolnych do języka polskiego dla szkół średnich Nowe lustra świata; wykładowca technologii multimedialnych w pracy nauczyciela polonisty na Uniwersytecie Jagiellońskim; trener technik edukacyjnych i rozwoju.

W swojej pracy z jednej strony zwraca uwagę na wykorzystanie nowoczesnych technik metodycznych (w tym multimedialnych), z drugiej - na harmonijne współistnienie na zajęciach elementów zadaniowych i procesowych - według niego nauka ma nie tylko wyposażać w określone narzędzia czy wiedzę, ale także dawać satysfakcję emocjonalną. 